\title{
Rainfall probability analysis for contingent crop planning in Keonjhar (Odisha)
}

\section{RAY}

Article Chronicle: Received: 25.04.2016; Accepted : 26.05.2016

Key Words : Probability analysis, Rainfed agriculture, Crop planning, Keonjhar
ABSTRACT : Rainfall is the most important but variable climatic parameter in suitable crop planning especially in the regions of rainfed agriculture. Rainfall data of 36 years (1980-2015) of Keonjhar district were analysed whose annual average rainfall is $892.53 \mathrm{~mm}$, with 52 numbers of rainy days, to find out the weekly, monthly and seasonal probability. Out of this $105.37,661.65$ and $125.51 \mathrm{~mm}$ is received in pre-monsoon (January-May), monsoon (June-September) and post monsoon (OctoberDecember) season, respectively. Probability for receiving more than $100 \mathrm{~mm}$ of rainfall can be expected only at 25 per cent probability level and that too in four weeks which is leading to the interpretation that rainfed rice production is a challenging task in this region. It has been found that at 75 per cent assured probability level rainfall of more than $250 \mathrm{mms}$ can be expected only in July and August months and this rainfall is hardly sufficient for meeting the water requirement in upland situations. However at 50 per cent probability which is equivalent to average condition, cultivation of rice is possible under well water management conditions or else some non- rice crops can be taken as an alternative. On seasonal basis rainfall at assured probability level of 75 per cent is not sufficient as the quantity is $465.4 \mathrm{~mm}$ rainfall in monsoon season.

HOW TO CITE THIS ARTICLE : Ray, M. (2016). Rainfall probability analysis for contingent crop planning in Keonjhar (Odisha). Asian J. Environ. Sci., 11(1): 106-110, DOI: 10.15740/HAS/AJES/11.1/106-110.
Author for correspondence :

\section{RAY}

Regional Research and Technology Transfer Station (O.U.A.T.), KEONJHAR (ODISHA) INDIA

Email : monikarayouat@ gmail.com 